\title{
ANTIAPOPTOSIS ACTIVITY OF PLANT POLYPRENYLPHOSPHATE AGAINST MACROPHAGE TARGET CELLS INFECTED WITH THE MURINE ENCEPHALOMYELITIS VIRUS
}

\author{
T.N. Kozhevnikova', A.V. Sanin' ${ }^{1}$, S.V. Ozherelkov ${ }^{2}$ \\ ${ }^{1}$ The Gamaleya Scientific Research Institute of Epidemiology and Microbiology, Moscow, Russia; \\ ${ }^{2}$ M.P.Chumakov Federal Scientific Center for Research and Development of Immunobiological Preparations, \\ Moscow region, Russia
}

\section{АНТИАПОПТОЗНАЯ АКТИВНОСТЬ РАСТИТЕЛЬНОГО ПОЛИПРЕНИЛФОСФАТА В ОТНОШЕНИИ КЛЕТОК-МИШЕНЕЙ МАКРОФАГОВ, ИНФИЦИРОВАННЫХ ВИРУСОМ МЫШИНОГО ЭНЦЕФАЛОМИЕЛИТА}

\author{
Т.Н. Кожевникова ${ }^{1}$, А.В. Санин ${ }^{1}$, С.В. Ожерелков ${ }^{2}$ \\ ${ }^{1}$ Национальный исследовательский центр эпидемиологии и микробиологии \\ имени почетного академика Н.Ф. Гамалеи, Москва; \\ ${ }^{2}$ Федеральный научный центр исследований и разработок иммунобиологических препаратов \\ им. М.П.Чумакова, Московская область
}

tatiana@micro-plus.ru

\begin{abstract}
Antiapoptosis activity of plant polyprenylphosphate against macrophage target cells infected with the murine encephalomyelitis virus. Infection caused by the Theiler's murine encephalomyelitis virus (TMEV) is regarded as an experimental model of multiple sclerosis, since both of these diseases are characterized by similar pathology of the central nervous system tissues and involvement of the immune system in the development of the demielinization. The aim of the work was to study the effect of plant-derived polyprenylphosphate (PP) on the apoptosis of infected target cells. We showed that PP reduced apoptosis of macrophage target cells infected with TMEV. It is known that in the protocol of multiple sclerosis treatment some medicines possessing immunomodulatory, antiviral, anti-inflammatory and antioxidant activity are used. Since PPs of plant origin also have all these activities, the prospects of their use as therapeutic agents are discussed.
\end{abstract}

Keywords: polyprenylphosphates; Theiler's murine encephalomyelitis virus; target cells; apoptosis.

Антиапоптозная активность растительного полипренилфосфата в отношении макрофагальных клеток-мишеней, зараженных вирусом мышиного энцефаломиелита Инфекция, вызываемая у мышей вирусом энцефаломиелита Тейлера (ВЭМТ), служит экспериментальной моделью рассеянного склероза, так как оба этих заболевания характеризуются сходной патологией тканей ЦНС и вовлечением иммунной системы в развитие процесса димиелинизации. Цель работы состояла в изучении воздействия полипренилфосфата (ППФ) растительного происхождения на апоптоз инфицированных ВЭМТ клеток-мишеней. Показано, что ППФ снижает апоптоз макрофагальных клеток-мишеней, инфицированных ВЭМТ. При терапии рассеянного склероза применяются средства, обладающие в том числе иммуномодулирующей, противовирусной, противовоспалительной и антиоксидантной активностью. Поскольку ПП растительного происхождения также обладают всеми указанными активностями, обсуждаются перспективы их применения в качестве терапевтических средств.

Ключевые слова: полипренилфосфаты; вирус энцефаломиелита мышей Тейлера; клетки-мишени; апоптоз.

Introduction. Infection caused by the Theiler's murine encephalomyelitis virus (TMEV) is regarded as an experimental model of multiple sclerosis, since both of these diseases are characterized by similar pathology of the central nervous system tissues and involvement of the immune system in the demielinization development [8]. The aim of the work was to study the effect of plant-derived polyprenylphosphate (PP) on the apoptosis of infected target cells.

Material and methods. We used the drug Gamapren (LLC "Gamavetfarm"), containing $5 \mathrm{mg} / \mathrm{ml}$ of PP obtained from mulberry leaves. TMEV (strain GDVII) was titrated in BHK
21 culture. The initial titer of the virus was 106PFU/ml. P388 D1 murine macrophage-like cell line was obtained from the American Cell Culture Collection (USA). The cells were cultured in RPMI1640 medium with $10 \%$ calf embryonic serum (Gibco). After 24 hours of incubation, the cells were infected with TMEV at a dose of 20-30 PFU/cell. PP $(100 \mu \mathrm{g} / \mathrm{ml})$ was then introduced into half of the infected cultures. The fluorescent dye Hoechst $33342(5 \mu \mathrm{g} / \mathrm{ml})$ was added into all cultures 30 minutes before the fixation of infected cells in order to detect apoptosis-specific changes in chromatin. After 5 hours of adsorption when pronounced signs of cytopathic action were 
manifested (cell swelling and chromatin condensation), the cells were fixed with $4 \%$ paraformaldehyde, then permeabilized with $0.5 \%$ Triton X-100 solution. Apoptotic cells were counted visually in an inverted light microscope Leica.

Results and discussion. We found that PP decreased viral-induced apoptosis of target cells. In 24 hours after TMEV infection, the number of apoptotic cells was 22\%, and reached $92 \% 48$ hours after infection. The inoculation of PP reduced the number of apoptotic cells, respectively, to $5 \%$ and $29 \%$ in 24 and 48 hours after infection.

Earlier studies have shown the ability of plantderived PP to inhibit the reproduction of DNA and RNA viruses in sensitive cell cultures [3, 4]. TMEV causes severe infection in mice, accompanied by the virus persistence in the central nervous sys- tem and the development of neuronal demielinization [8]. Reproduction of TMEV in P338 D1 cells results in the development of apoptosis accompanied by fragmentation of the chromatin [8]. Here we showed that PP significantly reduced the number of apoptotic cells in the infected cell culture.

In patients with multiple sclerosis, an increase in the level of pro-inflammatory cytokines is observed as well as a focus of inflammatory demyelination. For therapy of this disease agents with antiviral, anti-inflammatory, and antioxidant activity are used [9]. It is shown that plant-derived PPs, widely used in veterinary practice as antiviral and immunomodulatory medicines, are able to stimulate major cytokines production [2], and counteract various stress effects in vitro [7], as well as exhibit anti-inflammatory $[1,5]$ and antioxidant $[6]$ effects.

\section{References}

1. Ганшина И.В., Судьина Г.Ф., Санина В.Ю., и др. Фосфорилированные полипренолы - новый класс соединений с противовоспалительной и бронхолитической активностью // Инфекция и иммунитет. - 2011. - T. 1. - № 4. - С. 355-360.

2. Кожевникова Т.Н., Ожерелков С.В., Изместьева А.В., и др. Влияние препаратов Гамапрен и Фоспренил, созданных на основе полипренолов растительного происхождения, на продукцию некоторых регуляторных цитокинов в норме и при экспериментальном клещевом энцефалите у мышей // Российский иммунологический журнал. - 2008. - Т. 11. - № 2-3. - С. 250.

3. Ожерелков С.В., Белоусова Р.В., Данилов Л.Л., и др. Препарат фоспренил подавляет размножение вирусов диареи и инфекционного ринотрахеита крупного рогатого скота в чувствительных культурах клеток // Вопр. вирусол. - 2001. - Т. 5. - С. 43-45.

4. Ожерелков С.В., Калинина Е.С, Кожевникова Т.Н., и др. Экспериментальное исследование феномена антителозависимого усиления инфекционности вируса клещевого энцефалита in vitro // ЖМЭИ. - 2008. - № 6. - С. 39-43.

5. Санин А.В., Суслов А.П., Третьяков О.Ю., и др. Разнонаправленное влияние MIF и полипренилфосфата на течение экспериментальной флавивирусной инфекции у мышей // Ж. микробиол. 2011. - № 5. - C. 56-61.

6. Санин А.В., Наровлянский А.Н., Пронин А.В., и др. Изучение антиоксидантных свойств Фоспренила в различных биологических тест-системах // РВЖ МДЖ. - 2017. - № 10. - С. $28-31$.

7. Санин А.В., Наровлянский А.Н., Пронин А.В., и др. Эффективность фоспренила при профилактике экспериментального стресса in vitro // Ветеринария. - 2016. - № 10. - С. 11-13.

8. Roos RP. Infection of macrophages by Theiler's Virus. J.of Virology. 2002;76(24):12823-12833.

9. Luessi F, Siffrin V, Zipp F. Neurodegeneration in multiple sclerosis: novel treatment strategies. Expert Rev Neurother. 2012;12(9):1061-76. 